\title{
THE ORCHIDACEAE OF PRIMITIAE FLORAE ESSEQUEBOENSIS (1818)
}

\author{
Carlos Ossenbach \\ Orquideario 25 de Mayo, San José, Costa Rica \\ and Lankester Botanical Garden, University of Costa Rica \\ caossenb@racsa.co.cr
}

\begin{abstract}
AвstRact. The German botanist and Professor at the University of Göttingen, Georg Friedrich Wilhelm Meyer (1782-1856), studied the plants collected in the Dutch colony of Essequibo by Ernst Carl Rodschied and those kept in the herbarium of Professor Franz Karl Mertens, which he had received from a Dutch colonist during the early 1800s. On that basis, he published in 1818 his work Primitiae Florae Essequeboensis, describing 344 species of plants. Among them there are five species of orchids, two of which were new to science.
\end{abstract}

KeY wORDs: Essequibo, Georg Friedrich Wilhelm Meyer, Guiana, Orchidaceae

Essequibo (or Essequebo in Dutch) was a Dutch colony on the northern coast of South America from 1616 to 1814 (Fig. 1). It was founded between the Essequibo River on the west and the Demerara River on the east, on the eastern border of the Spanish General Captaincy of Venezuela in the Guiana region. It formed a part of the settlements that are known under the collective name of Dutch Guiana. Essequibo's

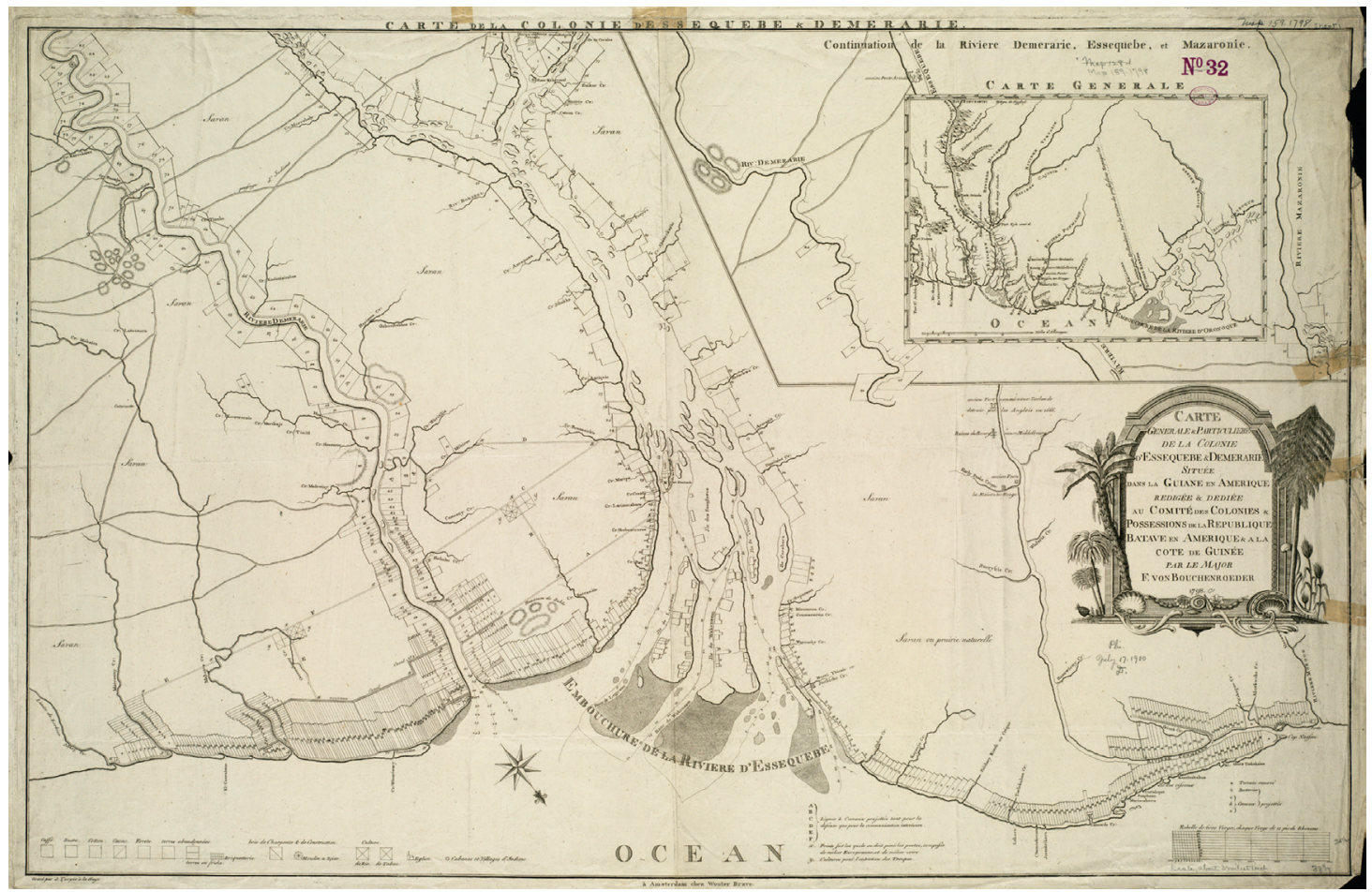

Figure 1. Carte generale et particuliere de la colonie d'Essequebe \& Demerarie située dans la Guiane en Amérique. Brave \& Wouter (1798).

Received 3 July 2018; accepted for publication 11 December 2018. First published online: 17 December 2018. Licensed under a Creative Commons Attribution-NonCommercial-NoDerivs 3.0 Costa Rica License 


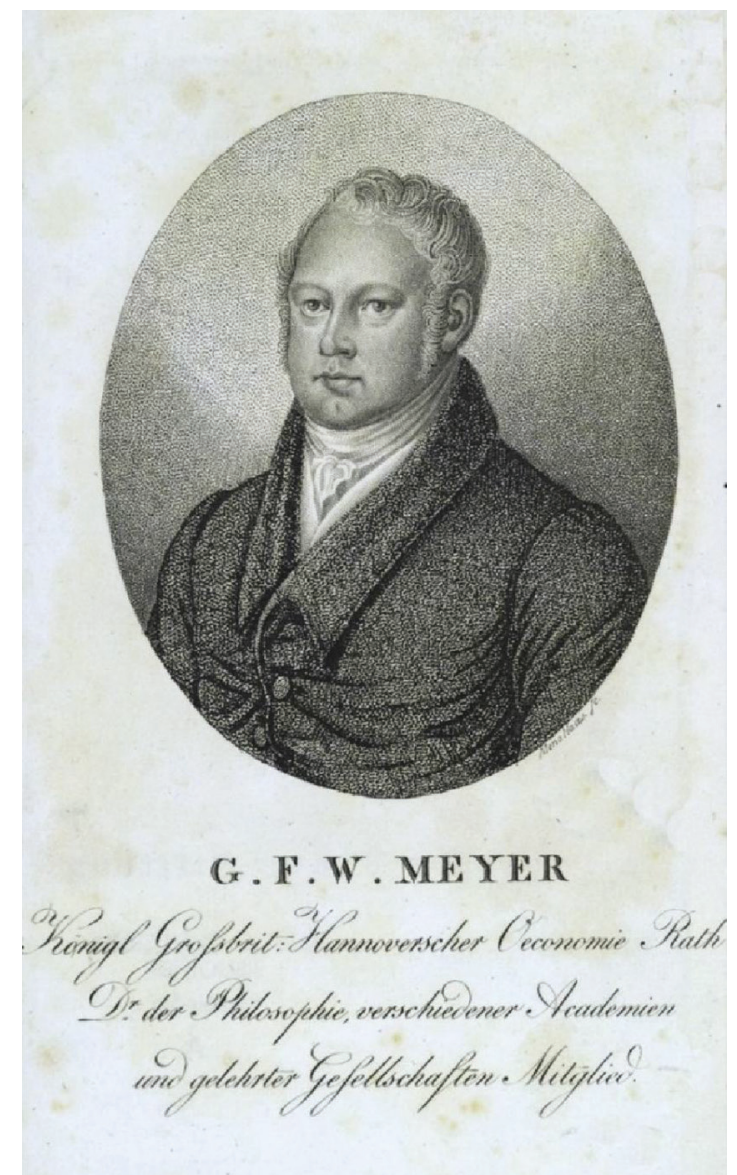

FiguRE 2. Georg Friedrich Wilhelm Meyer (1782-1856). Engraving by Meno Haas.

main town was the small city of Starbroek.

Essequibo and Demerara were captured by the British in 1781, then the colonies were occupied by the French until in 1783 the Peace of Paris restored the territories to the Dutch. The British occupied Essequibo again in 1796 and gave it back for a short time to the Netherlands as a consequence of the Peace of Amiens, from 1802 to 1803 . After that it was again taken by the British during the Napoleonic wars. The British never left again and Essequibo became officially British territory in 1814 as part of the Treaty of London. Starbroek was renamed as Georgetown. The colonies of Essequibo and Demerara were merged into British Guiana.

Georg Friedrich Wilhelm Meyer (1782-1856) was a German botanist and Professor for Forestry at the University of Göttingen (Fig. 2). He had studied

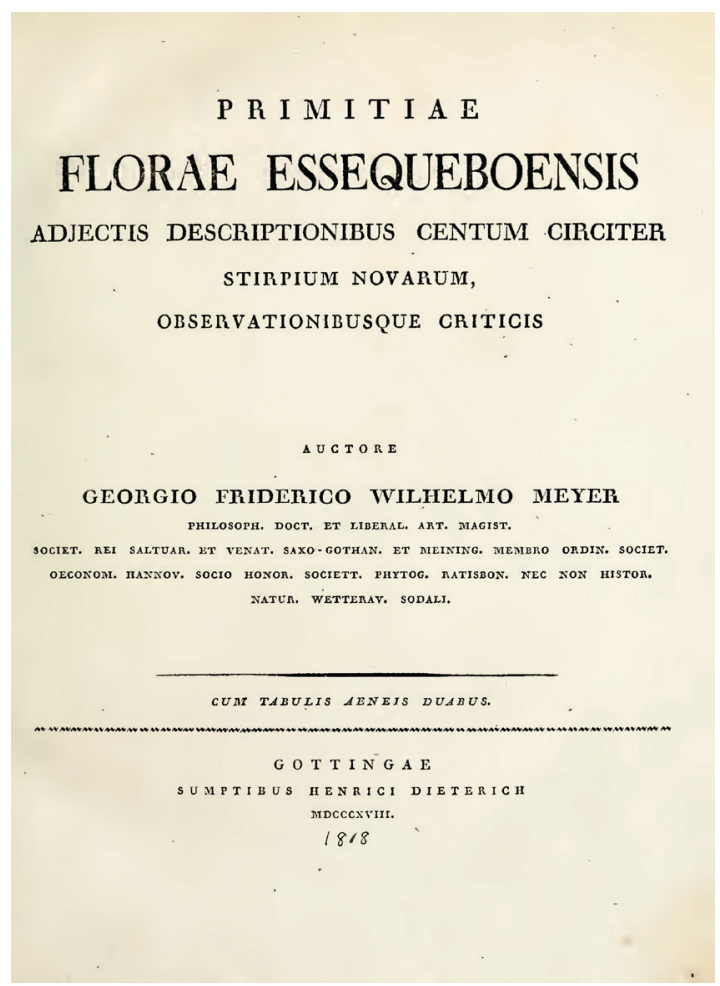

FIgure 3. Title page of Primitiae Florae Essequeboensis.

Forestry and Natural History between 1801 and 1805 in Göttingen and Dillingen and came in 1813 under employ of the Prussian Government as Forestry Inspector and then Director of Forests in Paderborn, Corvey and Höxter. He continued his studies in Göttingen and received in 1818 his Ph.D.

It was at that time that Meyer became interested in tropical botany, especially after he had the opportunity to purchase the herbarium of Ernst Carl Rodschied (?-1796). Rodschied was a German physician and botanist who had emigrated to Essequibo in 1790 in the service of the Dutch West-India Company and had lived there until his death in 1796. Rodschied wrote several small works about climate, social circumstances, and health problems of the population of the colony, and made frequent botanical excursions along the rivers Demerara and Essequibo (Baldinger 1796).

Meyer was also fortunate to make the acquaintance of Professor Franz Karl Mertens (17641831), a botanist from the city of Bremen, who had a second collection of plants from Essequibo, which he 


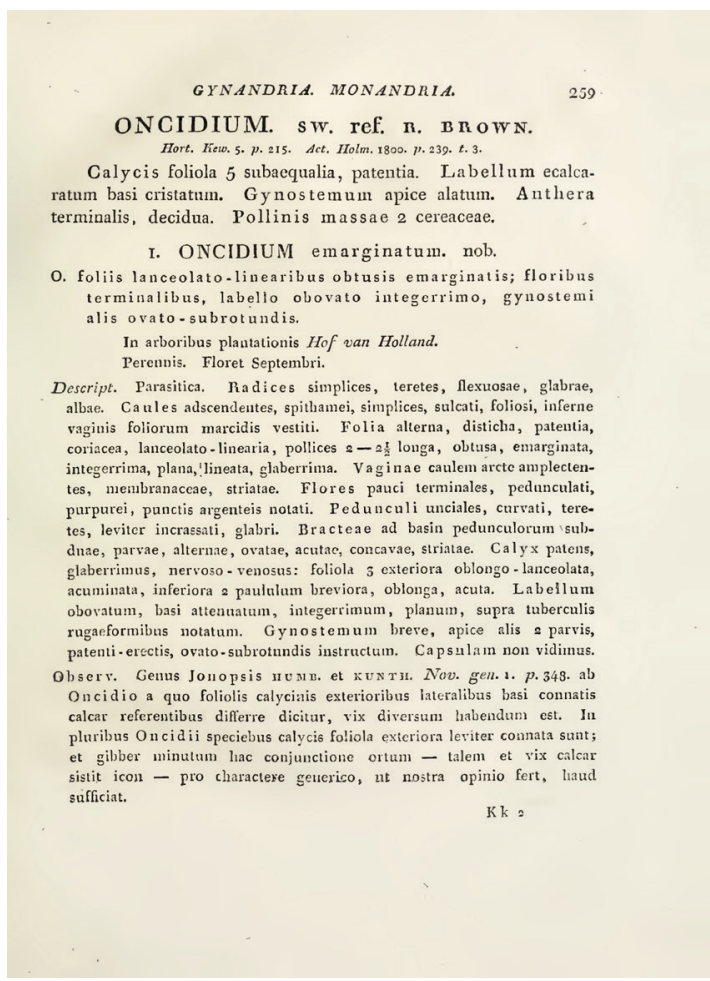

FIgURE 4. Protologue of Oncidium emarginatum, from Primitiae Florae Essequeboensis.

had received from a Dutch colonist during the early 1800s. These he gave to Meyer on loan.

Based on both Rodschied's and Mertens' collections, Meyer published in 1818 an important work, under the title Primitiae Florae Essequeboensis adjectis descriptionibus centum circiter stirpium novarum, observationibusque criticis (Fig. 3), in short words a precursor to a flora of the colony in which 344 species of plants were described, of which 118 turned out to be new to science (Anonymous 1819a, 1819b, 1820).

Five species of orchids are mentioned in Meyer's Flora, among them two that were new to science: Cymbidium trinerve G.Mey. [=Cyrtopodium andersonii (L.) Lindl.], Oncidium emarginatum G.Mey. [=Dimerandra emarginata (G.Mey) Hoehne], new to science (Fig. 4), Epidendrum ciliare L., Epidendrum flexuosum G.Mey, yet again a new orchid species, and Vanilla aromatica Sw. Oncidium emarginatum was collected by Rodschied on trees in the sugar plantation Hof van Holland.

The type specimen of Oncidium emarginatum

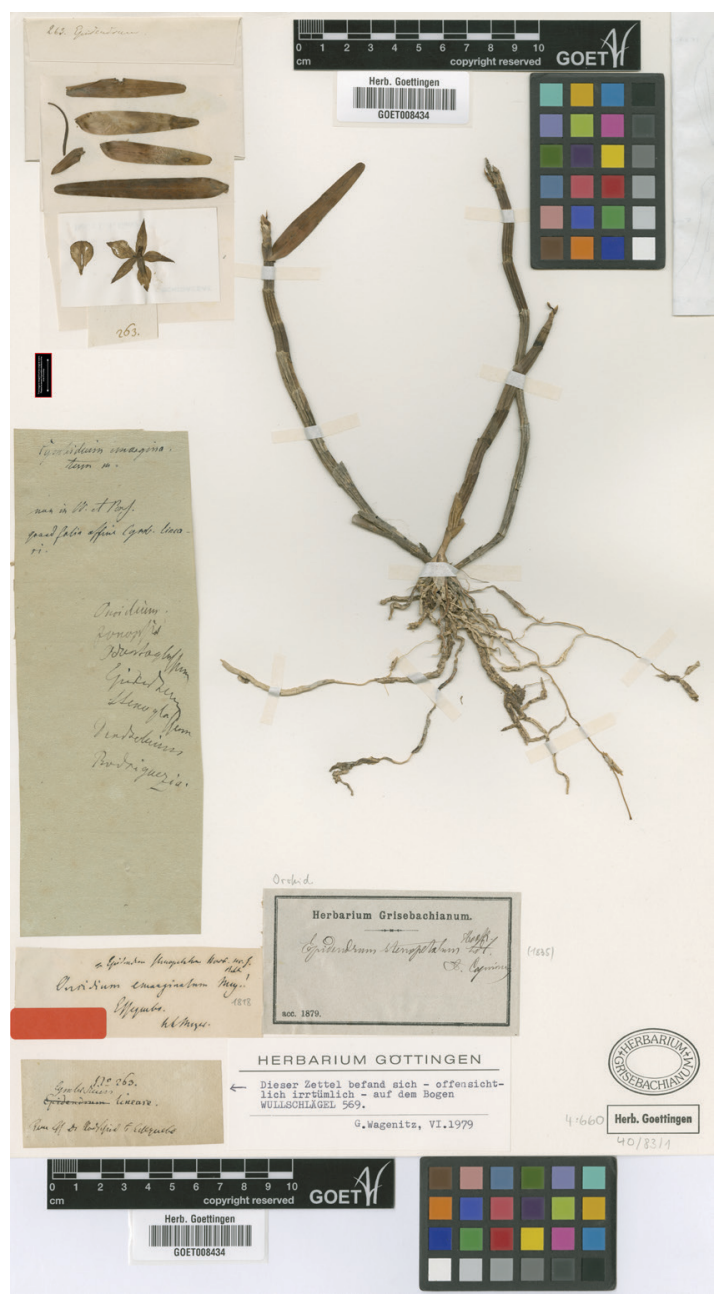

FIGURE 5. Type specimen of Oncidium emarginatum G.Mey. Herbarium of Göttingen University, Germany (GOET008434). Courtesy of the curator, Dr. Marc Appelhans.

together with a flower analysis by Leslie A. Garay can be found at the herbarium of the University of Göttingen, Germany (Fig. 5-6).

Acknowledgements. Special thanks to Dr. Marc Appelhans, Curator of the Herbarium of the University of Göttingen, for valuable copies of the type specimen of Oncidium emarginatum.

\section{Literature Cited}

Anonymous. (1819a). Meyer flora Essequeboensis. Heidelberger Jahrbücher der Litteratur, 12(1), 33-41. 


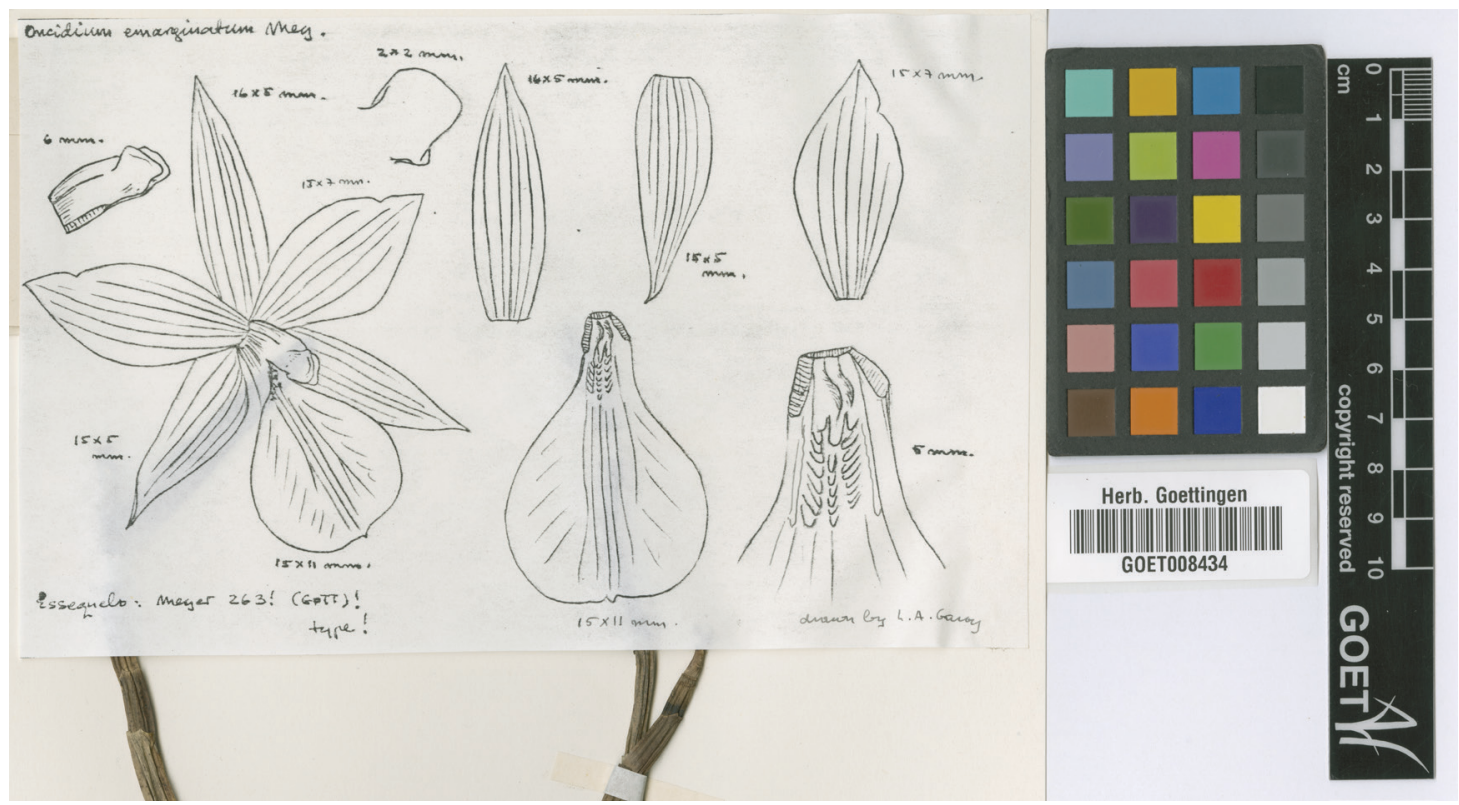

Figure 6. Oncidium emarginatum. Flower analysis by Leslie A. Garay from the type specimen.

Anonymous. (1819b). Primitiae Flora Essequeboensis. Flora oder Botanische Zeitung, 2(1), 337-344.

Anonymous. (1820). Primitiae Flora Essequeboensis. Jenaische Allgemeine Literatur-Zeitung, 17(4), 292294.

Baldinger, E. G. (1796). Ernst Carl Rodschied, Arztes zu
Rio Essequebo, Leben. Neues Magazin für Aerzte, 18(18), 203.

Meyer, G. F. W. 1818. Primitiae Florae Essequeboensis adjectis descriptionibus centum circiter stirpium novarum, observationibusque criticis. Göttingen: Heinrich Dieterich. 